\title{
Performance of tractor operated seed drill for direct seeding in rice
}

NARENDRA HARIDAS TAYADE

Received : 28.11.2016; Revised : 20.03.2017; Accepted : 28.03.2017

Author for Correspondence :

NARENDRA HARIDAS TAYADE

Krishi Vigyan Kendra, DANTEWADA (C.G.) INDIA
ABSTRACT : The study was conducted to assess the performance of tractor operated seed drill for sowing of rice seeds at Krishi Vigyan Kendra, Dantewada. The field tests were conducted on sandy soil. The treatments were random transplanting of seedling at 35 to 45 days with two hand weeding $\left(\mathrm{T}_{1}\right)$ and direct drilling of rice seeds in friable soil condition by seed drill at the onset of monsoon with one hand weeding. The field capacity and average yield was found to be $0.46 \mathrm{ha} / \mathrm{hr}$ and $35.00 \mathrm{q} / \mathrm{ha}$, respectively compared to $0.120 \mathrm{ha} / \mathrm{hr}$ and $29.90 \mathrm{q} / \mathrm{ha}$ observed in case of conventional method. The tractor operated seed drill was found to be better compared to conventional method of transplanting of paddy seedlings. The technology assessed better performance over farmers practice to reduce cost of cultivation and increase net profit.

- KEY WORDS : Drilling, Transplanting, Seed drill, Field capacity

- HOW TO CITE THIS PAPER : Tayade, Narendra Haridas (2017). Performance of tractor operated seed drill for direct seeding in rice. Internat. J. Agric. Engg., 10(1) : 199-201, DOI: 10.15740/HAS/ IJAE/10.1/199-201. 